Case Report:

\title{
Fazio-Londe Syndrome and Patient-centered Nursing Care: A Case Report
}

\author{
Mohammad Abdi $^{1 *}$ (D), Maryam Jolfaei² (D), Maryam Ghasemi ${ }^{2}$ (D), Mohammad Reza Dinmohammadi ${ }^{3}$ (D), Hojjat Torkmandi ${ }^{4}$ (D), Elmira \\ Khademi ${ }^{5}$ (iD \\ 1. Department of Emergency and Critical Care, Faculty of Nursing and Midwifery, Zanjan University of Medical Sciences, Zanjan, Iran. \\ 2. Department of Nursing and Midwifery School, Zanjan University of Medical Sciences, Zanjan, Iran. \\ 3. Department of Critical Care Nursing, Nursing and Midwifery School, Zanjan University of Medical Sciences, Zanjan, Iran. \\ 4. Department of Operating Room, Faculty of Nursing and Midwifery, Zanjan University of Medical Sciences, Zanjan, Iran. \\ 5. Department of Nursing, Maragheh Branch, Islamic Azad University, Maragheh, Iran.
}

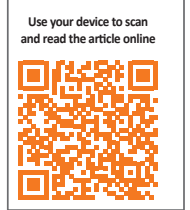

Cltation: Abdi, M., Jolfaei, M., Ghasemi, M., Dinmohammadi M., R., Torkmandi, H., Khademi, E., 2020. Fazio-Londe Syndrome and Patient-centered Nursing Care: A Case Report. Journal of Client-Centered Nursing Care, 6(2), pp. 135-144. https:/ doi.org/10.32598/JCCNC.6.2.275.2

doi) https://doi.org/10.32598/JCCNC.6.2.275.2

\section{(c) (1) (s)}

Article info:

Received: 02 Feb 2020

Accepted: 28 Mar 2020

Published: 01 May 2020

Keywords:

Fazio-londe, Nursing care, Patient-centered model of care, Brown-vialetto-van laere syndrome, Case report

\section{A B S T RA C T}

Introduction: Fazio-Londe disease is a genetic rare disorder manifesting by acute respiratory distress. This article is a case report of Fazio-Londe syndrome, its comparison with other case reports in the literature, and its patient-centered nursing care.

Case presentation: In this study, we reported a case with Fazio-Londe syndrome with respiratory distress, bulbar palsy, muscle weakness, and other symptoms.

Management and outcome: The patient was treated with oral riboflavin (100 mg/day), ribavirin (200 mg/day), and intramuscular Vit-B12 (1000 mg/day). She was managed using a patientcentered nursing care model.

Discussion: Health care providers should be aware of the new and constant symptoms of this rare disease. A patient-centered nursing care model is suggested to manage the disease.

\section{* Corresponding Author:}

Mohammad Abdi, Instructor.

Address: Department of Emergency and Critical Care, Faculty of Nursing and Midwifery, Zanjan University of Medical Sciences, Zanjan, Iran. Tel: +98 (912) 4530141

E-mail: mohammad2016@zums.ac.ir 


\section{Highlights}

- Fazio-Londe disease is a genetic rare disorder manifesting by acute respiratory distress.

- Health care providers should be aware of the new and constant symptoms of this rare disease.

- A patient-centered nursing care model is suggested to manage the disease.

\section{Plain Language Summary}

This article is a case report of Fazio-Londe syndrome, its comparison with other case reports in the literature, and its patient-centered nursing care. The health care providers are recommended to follow the home care of Fazio-Londe syndrome patients and consider that this syndrome may be accompanied by new manifestations, such as Ponto bulbar palsy (difficulty swallowing, weak jaw and facial muscles, progressive loss of speech, and weakening of the tongue), muscle pain, chills, sputum, and cyanosis. Also, the patient-centered nursing care model is suggested for providing care for these patients.

\section{Introduction}

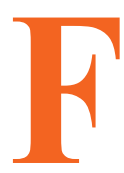

azio Londe is a form of Brown-Vialetto-Van Laere Syndrome (BVVLS) (Bosch, 2011). BVVL syndrome is a rare autosomal recessive neurological disorder, which was first described by Brown in 1894 and later by Vialetto and Van Laere (Manole et al. 2017; Bandettini Di Poggio et al. 2014). A patient with BVVLS typically manifests developing bulbar signs and symptoms, sensorineural alopecia, and respiratory failure (Davis et al. 2016). It is an autosomal recessive inherited disease caused by mutations in intestinal riboflavin transporter genes (Garg et al. 2018). The disease is so sporadic because, by 2016, there have been fewer than 100 reports of BVVLS, which shows its rare incidence (Davis et al. 2016).

Women are more likely to be affected by the disease, which can reflect a critical and lethal presentation in men. The recovery period is irregular and varies from a month to several years. Fazio Londe manifests by auditory neuropathy, bulbar palsy, stridor, muscle weakness, low level of consciousness, and respiratory suppression, which is represented by diaphragmatic and vocal cord paralysis (Chaya et al. 2018). Respiratory suppression is the most common cause of death (Shi et al. 2019).

Due to the fluctuations in the length of the disease and patients' conditions, a special model of nursing care is required. Because of the pathophysiology of the disease, most of these patients experience severe respiratory distress in the emergency department and need careful assessment and special care, such as airway management, respiratory monitoring, and oxygen therapy (Gowda et al. 2018; Abbas et al. 2018). They may be admitted to the intensive care unit (ICU) because of acute respiratory problems related to the progressive nature of the disease (Ersoy et al. 2015). After ICU admission, appropriate respiratory nursing care, such as respiratory physiotherapy and airway suctioning is needed. Also, fluid intake should be sufficient to prevent the development of respiratory distress. Other nursing care practices are breath control training, soft diet, and teaching proper swallowing techniques to prevent aspiration, communication techniques training, and promoting self-care activities (Ersoy et al. 2015).

Regarding the variations in patient conditions, if only routine care and hospital guidelines are provided, the patients' needs are not met. The patient-centered care model with its capabilities can be a good care model for these patients. This method provides individual care; so that compared with the medical approach, the simultaneous consideration of the patient's physical, mental, and social health in this approach is more prominent. The purpose of the service is to focus on core activities that directly affect the patient's needs (Gowda et al. 2018; Abbas et al. 2018). In this article, we reported a case of the Fazio-Londe syndrome and compared it with other case reports of the same disease in the literature. Also, we discussed the use of a patient-centered nursing care model in this case.

\section{Case Presentation}

A 39-year-old female patient, with speech and swallowing disorders, hypotonia, dysphagia, and hearing 


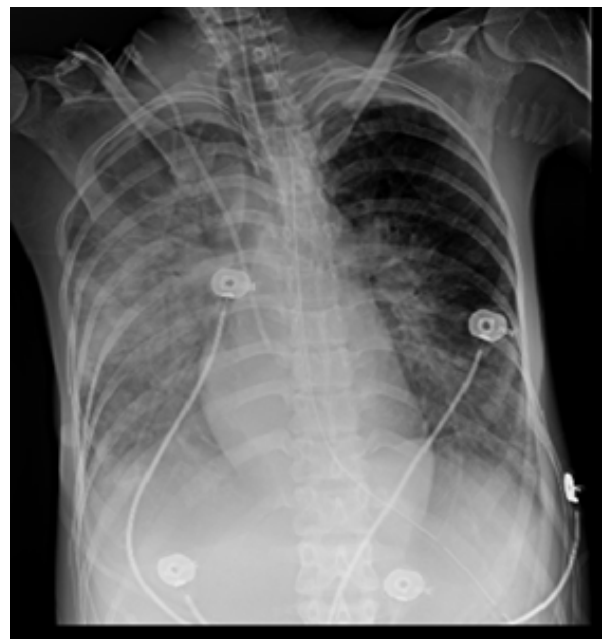

Figure 1. Chest X-ray upon admission (A) and after a week (B)

loss had been diagnosed with Fazio-Londe since the age of 17 and has been treated with Riboflavin $(100 \mathrm{mg} /$ day $)$. She discontinued treatment a year ago. Electromyography (EMG) and nerve Conduction Velocity Test (NCV) were performed five years ago following neurofascial problems and riboflavin deficiency.

The patient was admitted with the symptoms of cough, sputum, fever, chills, myalgia, Ponto bulbar palsy, dysphagia, and respiratory distress. She received O2 therapy using a non-rebreathing mask (15 L/min), azithromycin $500 \mathrm{mg} /$ day, analgesic, and $0.9 \%$ saline. After the failure in recovery and the continued severe respiratory distress, tachypnea, and cyanosis, she was intubated and mechanically ventilated (SIMV mode). The patient's ECG result showed normal sinus rhythm with 87 rate/ min. Ultrasound was performed for kidney and bladder assessment, which showed increased bladder wall thickness that raised the possibility of cystitis. Also, the result of ABG showed metabolic and respiratory alkalosis (Table 1).
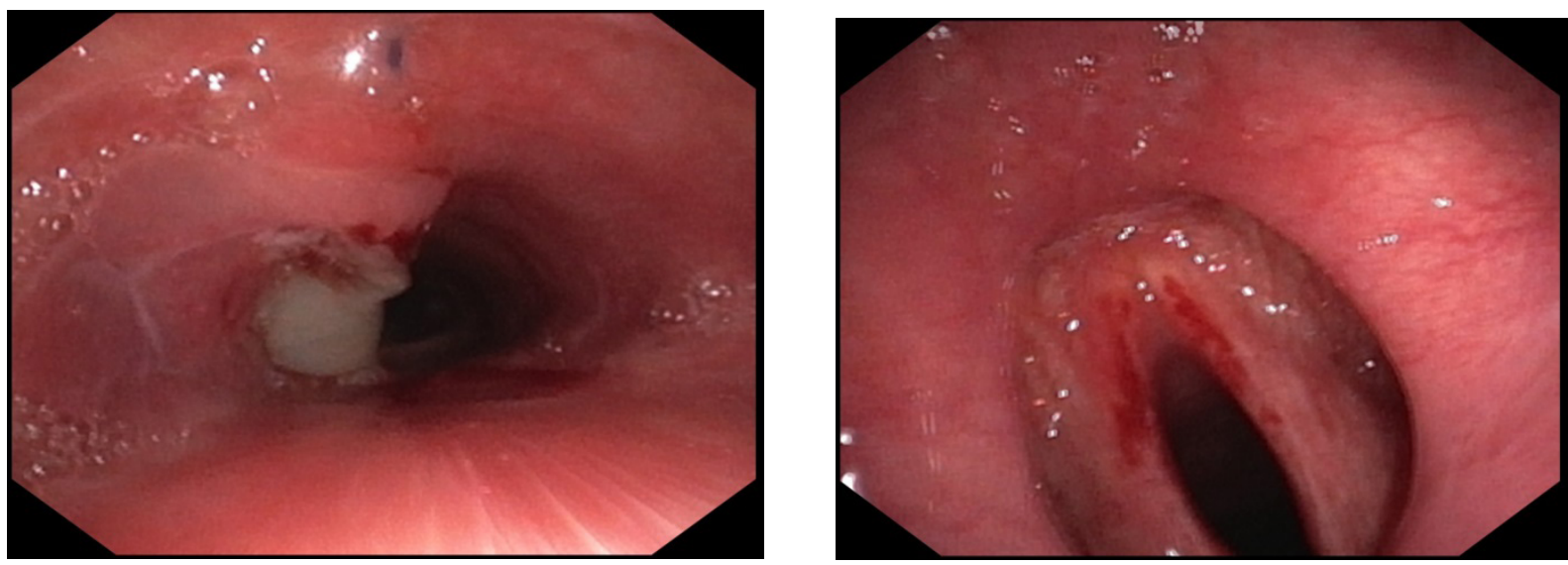

Figure 2: Diagnostic and therapeutic bronchoscopy was performed

\section{Management and Outcome}

The received medications included calcium gluconate infusion (30 mg/24 h), hydrocortisone (100 mg/q $12 \mathrm{~h}$ ), albumin 20\% (50 cc/day), addamel infusion/day, intramuscular Vit B12 (1000 mg/day), oral ribavirin (200 $\mathrm{mg} /$ day), combivent inhaler ( $\mathrm{q}$ 6h), and riboflavin (100 $\mathrm{mg}$ /day). The chest X-ray was performed due to increasing sialorrhea (excessive drooling) and tracheal secretion and pneumonia were detected (Figure 1). In order to better assessment of the lungs, the diagnostic-therapeutic bronchoscopy was performed; the infection site was washed out and suctioned (Figure 2). The patient received antibiotic therapy, including vancomycin $(1 \mathrm{~g} / \mathrm{q}$ $12 \mathrm{~h}$ ), levofloxacin ( $750 \mathrm{mg} / \mathrm{q} 12 \mathrm{~h})$, and cefepime ( $2 \mathrm{~g} / \mathrm{q}$ $12 \mathrm{~h})$. After a week the pneumonia was resolved. Due to the prolongation of the treatment process, tracheostomy was performed for the patient. With continued administration of riboflavin supplements, the patient's acute status improved. 
Table 1. The results of the patient's laboratory tests on admission and during hospitalization

\begin{tabular}{|c|c|c|}
\hline \multicolumn{3}{|c|}{ Blood Test } \\
\hline Laboratory Test & Admission Date & During Hospitalization \\
\hline $\mathrm{PH}$ & 7.54 & 7.43 \\
\hline PCO2 & 25 & 47.3 \\
\hline $\mathrm{HCO} 3$ & 21 & 18 \\
\hline $\mathrm{BE}$ & 0.7 & 5.9 \\
\hline BS & 77 & 98 \\
\hline WBC & 14000 & 8100 \\
\hline $\mathrm{Hb}$ & 9.2 & 11.6 \\
\hline CRP & - & 28.8 \\
\hline $\mathrm{Na}$ & 137 & 135 \\
\hline K & 4.2 & 4 \\
\hline BUN & 4 & 9.2 \\
\hline $\mathrm{Cr}$ & 0.4 & 0.6 \\
\hline LDH & 751 & 620 \\
\hline vitamin B-12 & 120 & 250 \\
\hline \multicolumn{3}{|c|}{ Urinary Analysis } \\
\hline Appearances & Tube Bid & Semi-Tube Bid \\
\hline Blood & $3+$ & $1+$ \\
\hline Protein & $1+$ & $1+$ \\
\hline Ketone & $2+$ & - \\
\hline Glucose & $1+$ & - \\
\hline WBC & $10-12$ & $2-5$ \\
\hline RBC & many & $5-6$ \\
\hline Urine culture & - & - \\
\hline
\end{tabular}

Nursing care for bulbar muscle weakness and salivary dysfunction included providing the patient with napkins (to maintain the patient's independence) to cleanse her saliva when she was able to use her hands for the first few days of hospitalization. However, due to muscle weakness, endotracheal suctioning was used to remove the secretions (Yaman Aktaş \& Karabulut, 2016). In the early days, a pen and paper were given to the patient to communicate with others. Over time, as the patient's condition worsened and she was not able to use her hands, she was given an alphabet board. We rubbed her legs to help to relieve her bone pain due to calcium deficiency. The family members were also taught about the patient's condition and the equipment needed (AmarDolan et al. 2020).

Finally, the patient was discharged with a home ventilator. At home, three nurses with detailed job descriptions provided home-based care at scheduled nursing shifts (Hwang \& Park, 2016). Four months after discharge, the patient's health was assessed. She could walk with a 

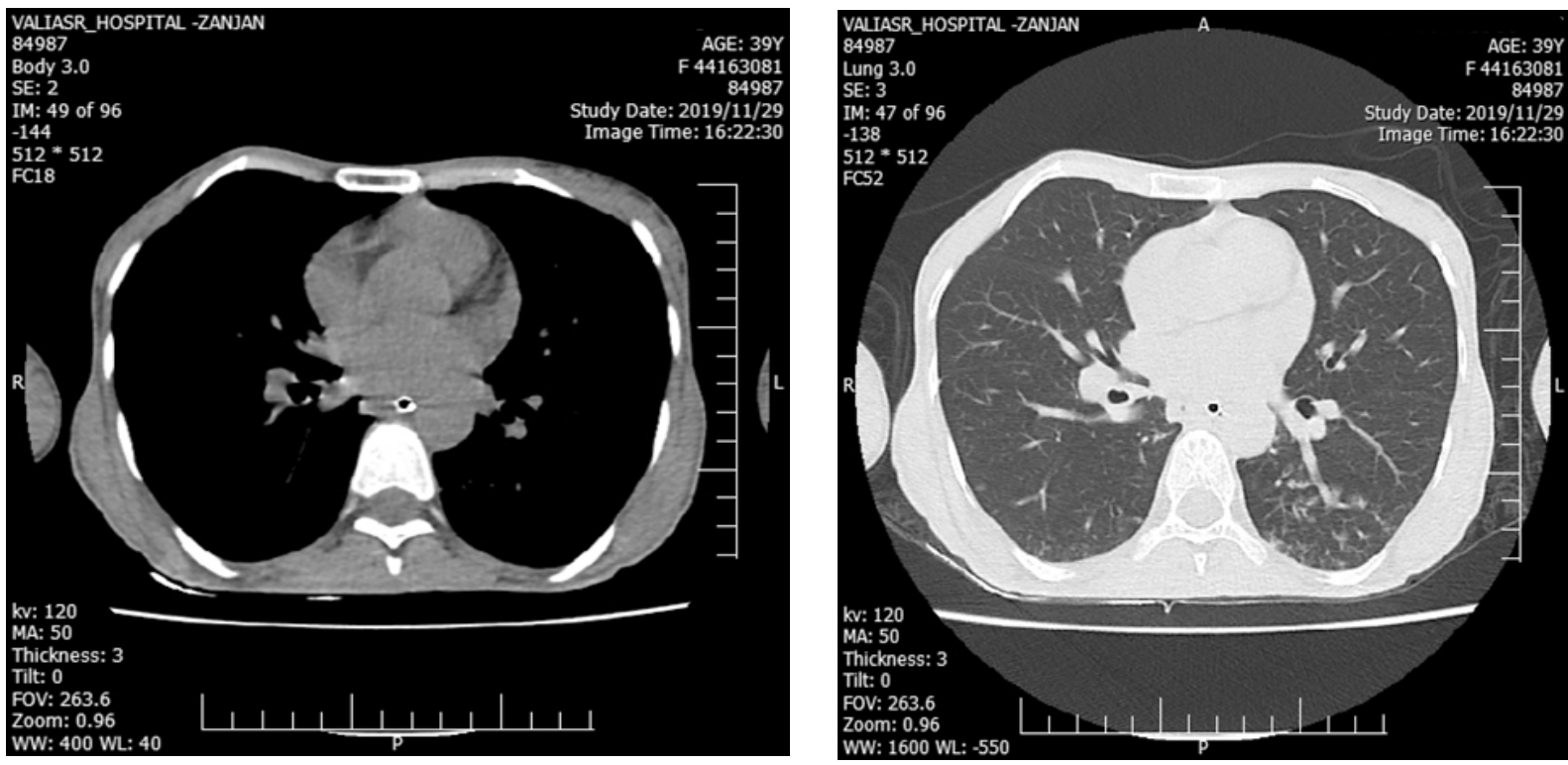

Client- Centered Nursing Care

Figure 3. Chest Computed Tomography (CT) scan before discharge from the hospital

walker, appeared in good spirits, and no signs of infection were seen on the chest Computed Tomography (CT) scan (Figure 3).

\section{Discussion}

We reported a rare case that has been little studied so far and we also reviewed the same case studies from 1990 to 2020. Data sources included PubMed, EMBASE, Google Scholar, DOAJ, Web of Science, and CINAHL without language restriction (Table 2). The studies have reported symptoms, such as hearing loss, difficulty in breathing, hypotonia, and dysphagia; however, our patient was diagnosed with symptoms of fever, chills, sputum, cough, myalgia, tachypnea, and cyanosis. One of the most variable features of this syndrome is its different clinical periods in different patients, so that it may be lethal (Mosegaard et al. 2017). Our patient developed symptoms of myalgia, tachypnea, and cyanosis due to the discontinuation of her medications. There is no common guideline for the treatment of these patients. Here, the drugs and their related dosage is discussed.

Riboflavin (7, 8-dimethyl-10-ribityl-isoalloxazine, vitamin B2) is a water-soluble vitamin, which is the precursor of the active coenzymes flavin mononucleotide $(\mathrm{FMN})$ and flavin adenine dinucleotide (FAD), important cofactors for carbohydrate, amino acid, and lipid metabolism (Jaeger \& Bosch, 2016). Riboflavin or vitamin B2 is indispensable and important for normal cellular functions, growth, and development in all aerobic forms of life (Suwannasom et al. 2020). The intake of riboflavin is dependent on milk, meats, fatty fish, and green vegetable intake.

The recommended daily allowance of riboflavin varies from $0.4 \mathrm{mg}$ (infants) to $1.6 \mathrm{mg}$ (lactating women) (Donohue et al. 2020). Excess riboflavin, FAD, and FMN are excreted in the urine. Besides the major supply from the diet, unknown amounts of riboflavin are generated by bacteria and absorbed in the large intestine (Said 2015). Presently, three riboflavin transporters have been characterized: RFVT1 is mostly expressed in the small intestine, RFVT 2 in the brain, and RFVT 3 in the small intestine (Jaeger \& Bosch, 2016).

The special nursing care model, which was used to maintain and enhance the patient's abilities, prevented complications, and made her aware of the importance of regular medication. No study has yet reported a nursing care model for these patients during the disease course. There are several models for patient care, such as case method, functional nursing, team nursing, primary nursing, and modular or district nursing (Mahulea et al. 2018). Regarding the fluctuations in the disease condition, the care should be based on the patient's changing needs; therefore, we used the patient-centered nursing care model.

In the patient-centered care model, patients' special health care needs and desired health outcomes are the driving force for all health care decisions and quality assessment (Bauchat et al. 2016). Patients communicate 
Table 2. A review of studies

\begin{tabular}{|c|c|c|c|c|c|c|c|}
\hline Author & Sex & $\begin{array}{l}\text { Age at the First } \\
\text { Symptom (y) }\end{array}$ & First Symptom & $\begin{array}{l}\text { Respiratory } \\
\text { Function }\end{array}$ & $\begin{array}{l}\text { Overall Maximal } \\
\text { Motor Function }\end{array}$ & Treatment & Response to Treatment \\
\hline $\begin{array}{l}\text { (Shi et al. } \\
\text { 2019) }\end{array}$ & Female & 1 & $\begin{array}{l}\text { Progressive mental } \\
\text { and motor regression, } \\
\text { breath-holding, and brain } \\
\text { stem dysfunction, includ- } \\
\text { ing facial weakness, hear- } \\
\text { ing loss, dysphagia. }\end{array}$ & $\begin{array}{l}\text { Breath- } \\
\text { holding }\end{array}$ & Motor regression & $\begin{array}{l}\text { High-dose } \\
\text { riboflavin } \\
\text { supple- } \\
\text { mentation }\end{array}$ & $\begin{array}{l}\text { The respiratory insuf- } \\
\text { ficiency and mental, } \\
\text { motor, and bulbar function } \\
\text { improved. However, sensor } \\
\text { neural hearing loss was not } \\
\text { improved }\end{array}$ \\
\hline $\begin{array}{l}\text { (Camar- } \\
\text { gos et al. } \\
2018)\end{array}$ & Female & 34 & Hearing and vision loss & Dyspnea & Quadriplegic & $\begin{array}{c}\text { Treat- } \\
\text { ment with } \\
\text { riboflavin } \\
(1,800 \mathrm{mg} / \\
\text { dav })\end{array}$ & $\begin{array}{l}\text { She could walk with a cane; } \\
\text { the feeding tube and non- } \\
\text { invasive ventilation were } \\
\text { withdrawn }\end{array}$ \\
\hline $\begin{array}{l}\text { (Thu- } \\
\text { lasi et al. } \\
\text { 2017), }\end{array}$ & Female & 6 & $\begin{array}{l}\text { Speech regression, pto- } \\
\text { sis, gait abnormality, and } \\
\text { choking }\end{array}$ & $\begin{array}{l}\text { Several } \\
\text { episodes of } \\
\text { choking }\end{array}$ & Gait ataxia & $\begin{array}{l}\text { Riboflavin } \\
\text { (60m/g } \\
\text { day) }\end{array}$ & $\begin{array}{l}\text { Normal gait, normal muscle } \\
\text { tone and deep tendon } \\
\text { reflexes, no tremor, and } \\
\text { mild left ptosis. Respiratory } \\
\text { effort had improved, but } \\
\text { sensor neural hearing loss } \\
\text { remained unchanged }\end{array}$ \\
\hline $\begin{array}{l}\text { (Ceren et } \\
\text { al. 2017) }\end{array}$ & Female & At birth & Irregular respiration & $\begin{array}{l}\text { Paradoxical } \\
\text { respiration }\end{array}$ & Hypotonia & $\begin{array}{c}\text { Oral } \\
\text { riboflavin } \\
(10-40 \mathrm{mg} / \\
\mathrm{kg} / \mathrm{d})\end{array}$ & $\begin{array}{l}\text { Spontaneous movements } \\
\text { in the patient's lower limbs } \\
\text { started and swallowing } \\
\text { dysfunction regressed with } \\
\text { the therapy of riboflavin }\end{array}$ \\
\hline $\begin{array}{l}\text { (Varada- } \\
\text { rajan et al. } \\
2015 \text { ) }\end{array}$ & Male & 11 & $\begin{array}{l}\text { Difficulty in: swallowing } \\
\text { liquids that progressed to } \\
\text { involve solid foods }\end{array}$ & $\begin{array}{l}\text { Respiratory } \\
\text { function: } \\
\text { breathless- } \\
\text { ness and } \\
\text { developed } \\
\text { respiratory } \\
\text { distress }\end{array}$ & $\begin{array}{l}\text { Power in all four } \\
\text { limbs was } 3 / 5\end{array}$ & $\begin{array}{l}\text { Riboflavin } \\
\text { therapy for } \\
6 \text { months }\end{array}$ & $\begin{array}{l}\text { He had no drooling of sa- } \\
\text { liva. Power in all four limbs } \\
\text { was } 4 / 5 \text {. The tone and } \\
\text { reflexes were normal. His } \\
\text { muscle wasting persisted. } \\
\text { He was able to walk on his } \\
\text { own. }\end{array}$ \\
\hline $\begin{array}{l}\text { (Garg et } \\
\text { al. 2018) }\end{array}$ & Female & 3 & $\begin{array}{l}\text { Progressive bilateral } \\
\text { hearing loss }\end{array}$ & $\begin{array}{l}\text { Developed } \\
\text { tachypnea }\end{array}$ & $\begin{array}{l}\text { Normal nerve } \\
\text { conduction in all } \\
\text { four limbs }\end{array}$ & $\begin{array}{c}\text { Oral ribo- } \\
\text { flavin at a } \\
\text { dose of } 10 \\
\mathrm{mg} / \mathrm{kg} / \mathrm{day} \\
\text { increased } \\
\text { to } 20 \mathrm{mg} / \\
\mathrm{kg} / \mathrm{day} \\
\text { after a } \\
\text { week }\end{array}$ & $\begin{array}{l}15 \text { days of starting treat- } \\
\text { ment, ptosis disappeared } \\
\text { and facial weakness and } \\
\text { palatal palsy improved. } \\
\text { After } 3 \text { months of follow-up } \\
\text { on riboflavin, the child has } \\
\text { a normal gag reflex and has } \\
\text { no facial weakness }\end{array}$ \\
\hline $\begin{array}{l}\text { (Mit- } \\
\text { tal and } \\
\text { Kamate, } \\
\text { 2019) }\end{array}$ & Male & 6 & $\begin{array}{l}\text { Complaints of dysphagia } \\
\text { for } 6 \text { months, hear- } \\
\text { ing loss for } 4 \text { months, } \\
\text { changes in voice for } 1 \\
\text { month, and respiratory } \\
\text { difficulty for } 15 \text { days }\end{array}$ & $\begin{array}{l}\text { Head bob- } \\
\text { bing with } \\
\text { labored } \\
\text { breathing } \\
\text { but there } \\
\text { was no } \\
\text { clinical } \\
\text { respiratory } \\
\text { distress }\end{array}$ & $\begin{array}{l}\text { Gross muscle } \\
\text { wasting }\end{array}$ & $\begin{array}{c}\text { High dose } \\
\text { riboflavin } \\
(20 \mathrm{mg} / \mathrm{kg} / \\
\text { day })\end{array}$ & $\begin{array}{l}\text { Within } 2 \text { to } 3 \text { weeks, the } \\
\text { jerky pattern of breathing } \\
\text { and swallowing improved, } \\
\text { and subsequently the child } \\
\text { started walking indepen- } \\
\text { / dently without ataxia. On } \\
\text { follow up, his hearing ability } \\
\text { also improved, and disuse } \\
\text { atrophy of appendicular } \\
\text { muscles also decreased }\end{array}$ \\
\hline $\begin{array}{l}\text { (Allison et } \\
\text { al. 2017) }\end{array}$ & Male & Two and a half & Worsening weakness & $\begin{array}{l}\text { obstructive } \\
\text { sleep apnea }\end{array}$ & $\begin{array}{l}\text { He was no longer } \\
\text { ambulating } \\
\text { and had diffi- } \\
\text { culty maintaining a } \\
\text { seated position. }\end{array}$ & $\begin{array}{l}\text { Riboflavin } \\
\text { therapy } \\
(10 \text { to } 50 \\
\mathrm{mg} / \mathrm{kg} / \mathrm{d})\end{array}$ & improvement in some areas \\
\hline $\begin{array}{l}\text { (Allison et } \\
\text { al. 2017) }\end{array}$ & Female & Two and a half & Hypotonia and areflexia & $\begin{array}{l}\text { No problem } \\
\text { mentioned }\end{array}$ & $\begin{array}{l}\text { Hypotonia and } \\
\text { areflexia }\end{array}$ & $\begin{array}{c}\text { Riboflavin } \\
\text { therapy } \\
\text { (50 mg/ } \\
\mathrm{kg} / \mathrm{d})\end{array}$ & $\begin{array}{l}\text { Improvements in her tone } \\
\text { and ataxia }\end{array}$ \\
\hline
\end{tabular}

with their health care providers, and the providers treat patients not only regarding their clinical status but also they concentrate on their emotional, psychological, spiritual, cultural, and economic status (Asarnow et al. 2017)
Our patient could communicate by speaking on the first day; however, she gradually lost the ability to speak and we had to use pen and paper. After a while, her muscle weakness progressed and she could not even write. For 
Table 3. Changes in disease complications and the required nursing care

\begin{tabular}{|c|c|c|c|}
\hline Trend of Nursing Care & Emergency & ICU & Home \\
\hline $\begin{array}{l}\text { FOUR Score/Glasgow } \\
\text { Coma Scale (GCS) }\end{array}$ & $\begin{array}{l}\text { FOUR Score: } 9 \\
\text { GCS: } 8\end{array}$ & $\begin{array}{l}\text { FOUR Score: 8-12 } \\
\text { GCS: 9-11 }\end{array}$ & $\begin{array}{l}\text { FOUR Score: } 12 \\
\text { GCS: } 11\end{array}$ \\
\hline Disability & $\begin{array}{l}\text { Difficulty in breathing } \\
\text { Inability to stand } \\
\text { Difficulty in completing sentences }\end{array}$ & $\begin{array}{l}\text { Inability to move } \\
\text { Aphasia } \\
\text { Dysphagia }\end{array}$ & $\begin{array}{l}\text { Immobility } \\
\text { Inability to breathe spontaneously } \\
\text { Difficulty in swallowing and speaking }\end{array}$ \\
\hline Nursing care & $\begin{array}{l}\text { History and physical examination } \\
\text { Respiratory monitoring and oxygen therapy } \\
\text { Immobilizing the patient (complete bed rest } \\
\text { (CBR)) }\end{array}$ & $\begin{array}{l}\text { Changing the position } \\
\text { Respiratory physiotherapy } \\
\text { Airway care }\end{array}$ & $\begin{array}{c}\text { Taking medication } \\
\text { Home ventilator care } \\
\text { Prevention of pneumonia } \\
\text { Prevention of mental disease }\end{array}$ \\
\hline
\end{tabular}

this reason, the alphabet board was used, and the patient communicated by pointing to the letters of the designed alphabet (Oldoini 2018). Then, the patient was even unable to point and all her movements disappeared. To solve the problem, we wrote 20 important sentences on a small board that included nutritional needs, defecation, anxiety, the need for airway support and suction, family support, and talking to the doctor (Teruya et al. 2019). The nurse showed the board intermittently to the patient and asked her for confirmation with eye movements.

Except for the communication aspect, these patients are at increased risk for bedsore, ventilator-associated pneumonia (VAP), foot muscle pain, and depression due to inactivity, muscle weakness, and intubation (Ghafari \& Ghane 2017). These problems were also present in our patient. Accordingly, her foot muscle pain improved by massaging, moving the legs and preventing the legs from overlapping, and warm compresses. Also, VAP was improved by appropriate fluid intake, respiratory physiotherapy, and sterile techniques during suctioning (Meng et al. 2015). Pressure ulcer was also prevented by checking skin condition, frequent change of the position, and keeping the skin dry and clean (Rodrigues, Ferreira \& Ferré-Grau 2016).

With the improvement of acute symptoms, the nasogastric tube, foley catheter, and other connections, which were used in the ICU were disconnected and she could take food through the mouth. She was taken out of bed several times before discharge. After training the patient and her family to use medical equipment and home care, she was discharged. Before discharge, a chest CT scan was taken to make sure the patient's lungs were clean (Figure 3). Three hospital nurses were responsible for training the patient at home and occasional home visits. The training was based on many aspects of care. For example, reducing the psychological problems, such as claustropho- bia and post-traumatic stress disorder were achieved by teaching relaxation techniques (Sadat et al. 2015).

Another aspect of family training was suctioning, home ventilator care, changing the patient's position, skincare, nutrition and gavage, and proper adherence to medication. Also, the need for mobility and exercise was instructed (Bishop, Walker \& Spivak. 2013). These patients may have complications, such as hypostatic pneumonia, insufficient muscle strength, and reduced body reflexes, like gag and cough reflexes. For this reason, a part of care is focused on preventing pneumonia (Pina et al. 2015). We used an incentive spirometer, effective cough training, and pursed-lip training for this patient, and also the patient's family were informed about the proper principles of airway care at home (Table 3 ). Regarding the fluctuation of the condition of these patients, it is better to adjust the type of care according to their condition.

\section{Conclusion}

The health care providers should follow up home care of Fazio-Londe syndrome and consider that this syndrome may be accompanied by new manifestations, such as Ponto bulbar palsy, myalgia, chills, sputum, and cyanosis. Also, the patient-centered nursing care model is suggested to care for patients with Fazio-Londe.

\section{Ethical Considerations}

\section{Compliance with ethical guidelines}

All ethical principles are considered in this article. 


\section{Funding}

This research did not receive any specific grant from funding agencies in the public, commercial, or non-profit sectors.

\section{Authors' contributions}

All authors contributed in preparing this article.

\section{Conflict of interest}

The authors declared no conflict of interest.

\section{Acknowledgments}

We thank the ICU nurses of Vali Asr Hospital in Zanjan. We also thank the patient and her family for their cooperation.

\section{References}

Abbas, Q., et al. 2018. Brown-Vialetto-Van Laere syndrome A novel diagnosis to a common presentation. BMJ Case Reports, 2018, p. bcr2018224958. [DOI:10.1136/bcr-2018224958] [PMID] [PMCID]

Allison, T., et al. 2017. Brown-Vialetto-Van Laere Syndrome as a mimic of neuroimmune disorders: 3 cases from the clinic and review of the literature. Journal of Child Neurology, 32(6), pp. 528-32. [DOI:10.1177/0883073816689517] [PMID]

Amar-Dolan, L. G., et al. 2020. This is how hard it is": Family experience of hospital-to-home transition with a tracheostomy. Annals of the American Thoracic Society, 17(7), pp. 860-8. [PMID] [DOI:10.1513/AnnalsATS.201910-780OC]

Asarnow, J. R., et al. 2017. The pediatric patient-centered medical home: Innovative models for improving behavioral health. The American Psychologist, 72(1), pp. 13-27. [DOI:10.1037/a0040411] [PMID]

Bandettini Di Poggio, M., et al. Brown-Vialetto-Van Laere syndrome: Clinical and neuroradiological findings of a genetically proven patient. Amyotrophic Lateral Sclerosis and Frontotemporal Degeneration, 15(1-2), pp. 141-4. [DOI:10.31 09/21678421.2013.837931] [PMID]

Bauchat, J. R., Seropian, M., \& Jeffries, P. R., 2016. Communication and empathy in the patient-centered care modelwhy simulation-based training is not optional. Clinical Simulation in Nursing, 12(8), pp. 356-9. [DOI:10.1016/j. ecns.2016.04.003]

Bishop, S. M., Walker, M. D., \& Spivak, I. M., 2013. Family presence in the adult burn intensive care unit during dressing changes. Critical Care Nurse, 33(1), pp, 14-24. [DOI:10.4037/ ccn2013116] [PMID]

Bosch, A. M., et al. 2011. Brown-Vialetto-Van Laere and Fazio Londe syndrome is associated with a riboflavin transport- er defect mimicking mild MADD: A new inborn error of metabolism with potential treatment. Journal of Inherited Metabolic Disease, 34(1), pp. 159-64. [DOI:10.1007/s10545010-9242-z] [PMID] [PMCID]

Camargos, S., et al. 2018. Late-onset and acute presentation of Brown-Vialetto-Van Laere syndrome in a Brazilian family. Neurology Genetics, 4(1), p. e215. [DOI:10.1212/ NXG.0000000000000215] [PMID] [PMCID]

Ceren, Ç., et al. 2017. P385 Hypotonic infant with riboflavin transporter deficiency due to slc52a 2 mutations. Archives Disease in Childhood, 102(Suppl_2), p. A181. [DOI:10.1136/ archdischild-2017-313273.473]

Chaya, S., et al. 2018. The first case of riboflavin transporter deficiency in sub-Saharan Africa. Seminars in Pediatric Neurology, 26, pp. 10-4. [DOI:10.1016/j.spen.2017.03.002] [PMID]

Davis, A., et al. 2016. Brown-Vialetto-Van Laere syndrome: A 28year follow-up. Journal of Neurology, Neurosurgery and Psychiatry, 87(6), pp. 681-2. [DOI:10.1136/jnnp-2014-310088] [PMID]

Donohue, J. A., et al. 2020. Micronutrient supplementation of lactating Guatemalan women acutely increases infants' intake of riboflavin, thiamin, pyridoxal, and cobalamin, but not niacin, in a randomized crossover trial. The American Journal of Clinical Nutrition, 112(3), pp. 669-82. [DOI:10.1093/ajcn/nqaa147] [PMID]

Ersoy, E. O., et al. 2015. Glutaric aciduria type 2 presenting with acute respiratory failure in an adult. Respiratory Medicine Case Reports, 15, pp. 92-4. [DOI:10.1016/j. rmcr.2015.02.009] [PMID] [PMCID]

Garg, M., et al. 2018. Riboflavin treatment in genetically proven Brown-Vialetto-Van Laere syndrome. Journal of Pediatric Neurosciences, 13(4), pp. 471-3. [DOI:10.4103/JPN. JPN_131_17] [PMID] [PMCID]

Ghafari, H., \& Ghane, M., 2017. Determination of frequency of bacterial agent causing ventilator associated pneumonia in the patients hospitalized in the intensive care unit of Tonkabon Shahid Rajaei Hospital by PCR sequencing. Zahedan Journal of Research in Medical Sciences, 19(3), p. e8039. [DOI:10.5812/zjrms.8039]

Gowda, V. K., et al. 2018. Fazio-Londe syndrome in siblings from India with different phenotypes. Brain and Development, 40(7), pp. 582-6. [DOI:10.1016/j.braindev.2018.02.010] [PMID]

Hwang, M. S., \& Park, J. H., 2016. Pneumonia incidence varies by tracheal suction procedures among caregivers of patients with home mechanical ventilators. Journal of Korean Academic Society of Home Health Care Nursing, 23(1), pp. 25-33. [DOI:10.22705/jkashen.2016.23.1.025]

Jaeger, B. \& Bosch, A., M., 2016. Clinical presentation and outcome of riboflavin transporter deficiency: Mini review af ter five years of experience. Journal of Inherited Metabolic Disease, 39(4), pp. 559-64. [DOI:10.1007/s10545-016-9924-2] [PMID] [PMCID]

Mahulea, C., et al. 2018. Modular Petri net modeling of healthcare systems. Flexible Services and Manufacturing Journal 30, pp. 329-57. [DOI:10.1007/s10696-017-9283-9]

Manole, A., et al. 2017. Clinical, pathological and functional characterization of riboflavin-responsive neuropathy. Brain, 140(11), pp. 2820-37. [DOI:10.1093/brain/awx231] [PMID] [PMCID] 
Meng, K., et al. 2015. The survey on implementation of evidence-based nursing in preventing ventilator-associated pneumonia and the effect observation. Cell Biochemistry and Biophysics, 71(1), pp. 375-81. [DOI:10.1007/s12013-0140208-x] [PMID]

Mittal, N., \& Kamate, M., 2019. Brown Vialetto Van Laere syndrome, a fatal disease with a simple solution: A case series. International Journal of Contemporary Pediatrics, 6(2), pp. 880-2. [DOI:10.18203/2349-3291.ijcp20190747]

Mosegaard, S., et al. 2017. An intronic variation in SLC52A1 causes exon skipping and transient riboflavin-responsive multiple acyl-CoA dehydrogenation deficiency. Molecular Genetics and Metabolism, 122(4), pp. 182-8. [DOI:10.1016/j. ymgme.2017.10.014] [PMID]

Oldoini, M. G., 2018. Hallucinosis and reverie: Alice's pain and its transformations in the consulting room. The International Journal of Psychoanalysis, 99(2), pp. 334-54. [DOI:10.1 080/00207578.2018.1429842]

PINA, J. C., et al. 2015. Presence and extent of the primary health care attributes among children hospitalized for pneumonia. Revista Latino-Americana De Enfermagem, 23(3), pp. 512-9. [DOI:10.1590/0104-1169.0502.2582] [PMID] [PMCID]

Rodrigues, A. M., Ferreira, P. L. \& Ferré-Grau, C., 2016. Providing informal home care for pressure ulcer patients: How it affects carers' quality of life and burden. Journal of Clinical Nursing, 25(19-20), pp. 3026-35. [DOI:10.1111/jocn.13356] [PMID]

Sadat, Z., Abdi, M., \& Aghajani, M., 2015. Prevalence of posttraumatic stress disorder and related factors among patients discharged from critical care units in Kashan, Iran. Archives of Trauma Research, 4(4), p. e28466. [DOI:10.5812/atr.28466] [PMID] [PMCID]

Said, H. M., 2015. Water-soluble vitamins. World Review of Nutrition and Dietetics, 111, pp. 30-7. [DOI:10.1159/000362294] [PMID]

Shi, K., et al. 2019. A Chinese pedigree with Brown-Vialetto-Van Laere syndrome due to two novel mutations of SLC52A2 gene: Clinical course and response to riboflavin. BMC Medical Genetics, 20(1), p. 76. [DOI:10.1186/s12881019-0811-1] [PMID] [PMCID]

Suwannasom, N., et al. 2020. Riboflavin: The health benefits of a forgotten natural vitamin. International Journal of Molecular Sciences, 21(3), p. 950. [DOI:10.3390/ijms21030950] [PMID] [PMCID]

Teruya, N., et al. 2019. Visiting nurses' perspectives on practices to achieve end-of-life cancer patients' wishes for death at home: A qualitative study. Asia-Pacific Journal of Oncology Nursing, 6(4), pp. 389-96. [DOI:10.4103/apjon.apjon_18_19] [PMID] [PMCID]

Thulasi, V., et al. 2017. A case of brown-vialetto-van laere syndrome due to a novel mutation in SLC52A3 gene: Clinical course and response to riboflavin. Los Angeles: SAGE Publications. [DOI:10.1177/2329048X17725610] [PMID] [PMCID]

Varadarajan, P., Thayanathi, V., \& Pauline, L. C., 2015. Fazio Londe syndrome: A treatable disorder. Annals of Indian Academy of Neurology, 18(1), pp. 87-9. [DOI:10.4103/09722327.144283] [PMID] [PMCID]

Yaman Aktaş, Y., \& Karabulut, N., 2016. The effects of music therapy in endotracheal suctioning of mechanically ven- tilated patients. Nursing in Critical Care, 21(1), pp. 44-52. [DOI:10.1111/nicc.12159] [PMID] 
This Page Intentionally Left Blank 